\title{
Ludmila Zając-Lamparska*
}

\section{TEMPORALNY WYMIAR OSOBOWOŚCI. PANORAMA STANOWISK}

\begin{abstract}
Celem artykułu jest dokonanie przeglądu i analizy psychologicznych koncepcji osobowości pod kątem obecności w nich zagadnienia czasu. Przeprowadzona analiza pozwala stwierdzić, że czas może pełnić rolę zewnętrznego kryterium opisu funkcjonowania osobowości bądź być obecnym w samej osobowości jako czas psychologiczny. Status zagadnienia czasu w psychologii osobowości ewoluował od problemu wtórnego, stanowiącego swoiste tło dla ważniejszych kwestii i tylko sygnalizowanego, do centralnego, stanowiącego podstawowy przedmiot rozważań, dyskusji i badań. Współcześnie temporalne aspekty osobowości są poddawane analizie i badaniom empirycznym przede wszystkim w nurcie poznawczym.
\end{abstract}

Słowa kluczowe: osobowość, czas psychologiczny, perspektywa temporalna, orientacja temporalna

\section{WPROWADZENIE}

Celem artykułu jest dokonanie przeglądu i analizy klasycznych koncepcji osobowości pod kątem obecności w nich zagadnienia czasu. Rudymentarne dla podjętego tematu jest stwierdzenie, iż osobowość ludzka jest temporalna. Jak argumentuje Trempała (2000), jako centralna instancja regulacji psychicznej organizuje ona doświadczenie i ukierunkowuje działanie w określonej czasoprzestrzeni. Czasowość osobowości rozpatrywać można w sposób dwojaki (Zając 2003). Po pierwsze czas pełnić może rolę zewnętrznego kryterium opisu funkcjonowania osobowości, jako parametr przebiegu wyznaczanych przez nią działań człowieka czy zachodzących w niej zmian. Ma on wówczas charakter obiektywny (a dokładniej zobiektywizowany), ponieważ wyznaczany jest przez sztuczny temporaż, tj. specjalnie skonstruowane mierniki czasu. W tym ujęciu czas może służyć jako narzędzie opisu funkcjonowania osobowości, jednak sam w sposób bezpośredni w funkcjonowaniu tym nie uczestniczy i o nim nie decyduje. Po drugie, czas może być także obecny w samej osobowości, jako czas psychologiczny. Nie jest on wówczas tylko parametrem, lecz jedną z osobowościowych właściwości psychicznych, mających wpływ na postępowanie jednostki. Oznacza to, iż czas psychologiczny stanowi nie tylko kategorię opisu funkcjonowania człowieka, lecz, przynależący do osobowości, jego aktywny czynnik sprawczy.

\footnotetext{
* Uniwersytet Kazimierza Wielkiego w Bydgoszczy; lzajac@ukw.edu.pl
} 


\section{ZAGADNIENIE TEMPORALNOŚCI W KLASYCZNYCH KONCEPCJACH OSOBOWOŚCI}

Większość koncepcji osobowości czyni określone założenia co do roli czasu w jej funkcjonowaniu (Pervin i Oliver 2002). Nie powinien przy tym w błąd wprowadzać brak terminologii, specyficznej dla problematyki temporalności. Założenia te formułowane są bowiem często „nie wprost”, tzn. bez konieczności skupiania się autora danej koncepcji na zagadnieniu czasu. Mogą one natomiast stanowić pochodną innych ustaleń dotyczących struktury, dynamiki czy rozwoju osobowości.

Wymiar temporalny jest obecny już w pierwszej pełnej ${ }^{1}$ teorii osobowości, tzn. w teorii Freuda. Freud wyeksponował rolę czasu przeszłego i podporządkował mu teraźniejszość oraz przyszłość (Freud 1995). Uznał on, że aktualne i przyszłe funkcjonowanie jednostki jest zdeterminowane jej przeszłymi doświadczeniami. Można to ująć jeszcze inaczej: teraźniejsze i przyszłe zachowanie jednostki stanowi, zdaniem Freuda, niejako powtórzenie (choć często manifestujące się na zewnątrz w innej formie) jej przeszłości (Stevens 2000). Generalnie psychoanalityczne podejście do osobowości człowieka łączy się z akcentowaniem znaczenia czasu przeszłego. Rzeczywiście, rolę przeszłych doświadczeń zaznaczali również kolejni przedstawiciele psychoanalizy. Zdaniem Adlera (1986) istotne znaczenie dla psychicznego funkcjonowania człowieka mają jego wczesne doświadczenia, a wśród nich: kolejność urodzenia w stosunku do rodzeństwa oraz doświadczanie rozpieszczania lub zaniedbywania przez rodziców. Także Jung opisuje możliwość wyjaśniania aktualnych zdarzeń z życia jednostki za pomocą przeszłości, i to nie tylko jednostkowej, lecz również gatunkowej, mieszczącej się w nieświadomości zbiorowej (Gałdowa 1999; Lindzey i Hall 1998). Wyjaśnianie takie określa on jako przyczynowe. Jednak przeszłe doświadczenia w myśl koncepcji Adlera i Junga nie implikują jednoznacznie i samodzielnie przyszłych losów jednostki, co odbiera czasowi przeszłemu część jego mocy sprawczej. Zdaniem Adlera (1986) człowiek posiada tzw. twórczą jaźń. Za jej pomocą interpretuje doświadczenia i nadaje im sens, a nawet poszukuje doświadczeń, które byłyby zgodne z tzw. stylem życia. W konsekwencji, dzięki twórczej jaźni, człowiek samodzielnie kształtuje swoją osobowość na podstawie dziedziczności i doświadczenia (Opoczyńska 1999). Ponadto Adler uwzględnia także rolę przyszłości i w jej kontekście rozpatruje aktualne procesy psychiczne i zachowanie jednostki (Adler 1986; Opoczyńska 1999). W myśl sformułowanej przez autora zasady fikcjonalngo finalizmu (Lindzey i Hall 1998), fikcyjne cele (które mogą być ulokowane w czasie przyszłym) stanowią subiektywną przyczynę tego, co zachodzi w psychice jednostki w czasie teraźniejszym. Z kolei Jung (tamże) postuluje konieczność uzupełniania przyczynowego wyjaśniania funkcjonowania jednostki wyjaśnianiem teleologicznym, czyli finalistycznym. Polega ono na interpretowaniu zdarzeń teraźniejszych w kategoriach przyszłości, tzn. kierunku, w którym zmierza osobowość. Autor utrzymuje, że pełne zrozumienie osobowości jest możliwe jedynie w przypadku stosowania obu rodzajów wyjaśniania, teleologicznego i przyczynowego.

1 Freud jako pierwszy stworzył koncepcję osobowości, opisującą trzy najistotniejsze jej aspekty: strukturę, funkcję i zmiany. 
Równie silny nacisk na czas przeszły, co klasyczna psychoanaliza Freudowska, kładą koncepcje osobowości, posługujące się schematem bodziec-reakcja. Przekonanie o roli przeszłości opiera się w nich jednak na odmiennych przesłankach. Czołowy przedstawiciel behawioryzmu, Skinner, definiuje ją jako zespół wzorców zachowania. Owe wzorce mają swe źródło w przeszłości, w której zostały wyuczone. To czyni czas przeszły determinantą aktualnego zachowania jednostki. Jednak w tym ujęciu pewne znaczenie ma także teraźniejszość. Po pierwsze, dostarczana przez nią stymulacja decyduje o tym, które z posiadanych nawyków czy wzorców zachowania zostaną uruchomione. Ponadto teraźniejsze doświadczenia mogą zmienić strukturę nawyków, składających się na osobowość. O ile będą one dostatecznie silne, często się powtarzające i odmienne od dotychczasowych, mogą doprowadzić do zastąpienia istniejących nawyków nowymi. Z takiego ujęcia czasu wnioskować można, iż przyszłość, rozpatrywana w ramach schematu S-R, stanowi przedłużenie teraźniejszości, a nawet przeszłości, co pozwala nie przywiązywać do niej dużej wagi. Wynika stąd, iż wysoka ranga czasu przeszłego jest tu eksponowana jeszcze bardziej radykalnie niż w przypadku psychoanalizy. Dla dokładności należy zaznaczyć, że behawioryści analizowali czas przede wszystkim w jego znaczeniu obiektywnym. Tak rozumiany czas stanowi jeden (bardzo istotny) z wymiarów, w jakich rozpatrywali oni mikrostrukturę zachowania (Nosal 2000). Natomiast o roli przypisywanej czasowi przeszłemu można wnioskować pośrednio, na podstawie analizy koncepcji tego nurtu. Jest to widoczne w wywodzącej się z niego koncepcji uczenia się Dollarda i Millera (1967). Podają oni, że osobowość stanowi zbiór nawyków, czyli skojarzeń bodźców z reakcjami, co oznacza jej przeszłe ukształtowanie się.

W sposób w pewnym zakresie zbliżony do psychoanalitycznego (lecz bardziej w wersji Adlera i Junga niż Freuda) znaczenie czasu dla osobowości opisuje Murray (Lindzey i Hall 1998). Jest on nastawiony na pełne zrozumienie indywidualnych przypadków, stąd w swej koncepcji koncentruje się na prywatnej historii życia człowieka, akcentując w ten sposób znaczenie przeszłości. Murray przyjmuje, że zdarzenia zachodzące w niemowlęctwie i dzieciństwie stanowią najistotniejsze determinanty funkcjonowania w wieku dojrzałym², a ,historia osobowości jest osobowością” (za: Lindzey i Hall 1998: 201). Jednocześnie odrzuca on pogląd o kluczowej roli nawyku w rozwoju osobowości. Zdaniem tego autora człowiek raczej poszukuje wciąż nowych sposobów wyrażania siebie i nowych form stymulacji, a także jest zdolny do wewnętrznej przemiany (Murray 1968, za: Lindzey i Hall 1998). Także sama osobowość realizuje, zdaniem Murraya, funkcje związane z przyszłością. Wśród zadań ego autor umieszcza planowanie, które związane jest z czasem przyszłym. Istotne z tego punktu widzenia są tzw. programy serii (serial programs, za: Lindzey i Hall 1998: 202; Mądrzycki 1996: 110), będące układami celów cząstkowych, uporządkowanych i służących osiąganiu określonego, pożądanego stanu końcowego. Programy serii mogą sięgać w przyszłość o różnym dystansie, od dni po lata. Uzupełnienie programów serii stanowią rozkłady czasowe (schedules, za: Lindzey i Hall 1998: 202), dzięki którym możliwa jest realizacja różnych celów w różnym czasie. Umożliwiają one redukcję konfliktów pomiędzy konkurencyjnymi

2 Stąd w Murrayowskim opisie rozwoju osobowości pojęcie kompleksu, jako zbioru doświadczeń wczesnego dzieciństwa, zajmuje centralną pozycję. 
tendencjami oraz maksymalizację osiągalności celów. W ten sposób Murray jest chyba pierwszym psychologiem, który podjął problematykę związaną z czasem przyszłym oraz celami i planami życiowymi (Mądrzycki 1996).

Z kolei jednym z pierwszych psychologów, który przypisał czasowi przeszłemu ograniczoną rolę jest Allport (1988). Twierdzi on, iż człowiek jest bardziej ukształtowany przez teraźniejszość niż przeszłość. Niezależność jednostki względem historii własnego życia autor wyjaśnia, wprowadzając pojęcie autonomii funkcjonalnej. Według zasady autonomii funkcjonalnej każde zachowanie może stać się celem samym w sobie, pomimo iż pierwotnie podejmowane było z innych powodów. Dzięki temu można zakładać współczesność motywów ludzkich i koncentrować się na teraźniejszości, nie zaś na przeszłości. Zdaniem Allporta doniosłą rolę pełni także przyszłość, a dokładniej zamiary jednostki. Pod pojęciem zamiarów kryją się dla autora wszelkie plany, nadzieje, ambicje i aspiracje człowieka. Są one lepszym predykatorem zachowania jednostki niż jej przeszłe doświadczenia. Jak podaje Allport, „trafny opis całego szeregu stanów umysłowych wymaga uwzględnienia przyszłych zdarzeń. Z dążeniami idą w parze zainteresowania, skłonności, dyspozycje, oczekiwania, planowanie, rozwiązywanie problemów i intencje" (Allport 1988: 45). Znaczenie celów i planów na przyszłość dla aktualnego funkcjonowania jednostki zauważali wprawdzie już Adler i Jung, jednak, zgodnie z założeniami nurtu psychoanalitycznego, podkreślali oni jednocześnie rolę przeszłości, natomiast koncepcja Allportowska zdecydowanie ją redukuje.

W swoisty sposób, odmienny od dotychczas opisanych, postrzegają czasowość osobowości psychologowie egzystencjalni (np. Binswanger, Boss). Nie wyodrębniają oni osobowości jako atrybutu człowieka, lecz analizują strukturę ludzkiej egzystencji, tzw. „bycia w świecie" (Heideggerowskiego Dasein, za: Lindzey i Hall 1998). Czas stanowi, zdaniem egzystencjalistów, jego niezbywalny aspekt. Nie chodzi przy tym o obiektywny wymiar czasu, o czas zegarowy czy kalendarzowy, zewnętrzny względem jednostki, lecz o czas dla niej znaczący. Jego znaczenie wynika stąd, iż jest on czasem „na coś”, tzn. człowiek pragnie go w jakiś sposób spożytkować. Uwzględniając rolę czasu, egzystencjaliści zdecydowanie odrzucają założenie o wczesnodziecięcych doświadczeniach czy nabytych nawykach jako czynnikach determinujących późniejsze postępowanie człowieka. Wyjaśniając zachowanie, odwołują się oni do aktualnej sytuacji jednostki i teraźniejszej specyfiki jej bytowania w świecie. Tłumaczą, iż nawet jeśli określone zachowanie występowało w przeszłości, jest powtarzane i u jego źródła znajdują się wciąż te same przyczyny, to ich działanie wynika ze znaczenia, jakie mają one dzisiaj, nie zaś, jakie miały w przeszłości (tamże). Odwoływanie się do teraźniejszości jednostki nie odbywa się jednak na drodze negacji dwóch pozostałych wymiarów czasu. Wprost przeciwnie, jak podaje Boss (tamże), przebywanie w świecie oznacza zawsze jednoczesne (a zarazem współczesne, zawsze teraźniejsze - przyp. autora) bytowanie w przeszłości, teraźniejszości i przyszłości. Czasowość jako wymiar ludzkiego bytowania jest bowiem, w ramach psychologii egzystencjalnej, rozpatrywana w kategoriach „otwartości na”. Człowiek, istniejąc fizycznie w teraźniejszości, może żyć nią albo też przeszłością czy przyszłością, będąc na nie otwartym w różnym stopniu. W ten sposób perspektywa czasowa jednostki może się poszerzać lub kurczyć, obejmując różne zakresy przeszłości i przyszłości. 
Nieco podobnie do egzystencjalistów opisują wymiar temporalny osobowości organicyści, choć dostrzeżenie tego podobieństwa utrudnia specyfika stosowanej w psychologii egzystencjalnej terminologii. Elementami wspólnymi obu tych ujęć są: uwzględnianie wszystkich wymiarów czasu jako istotnych dla funkcjonowania osobowości oraz koncentracja na teraźniejszości, przy jednoczesnym wskazaniu na „obecność” w niej przeszłości i przyszłości. Jeden z organicystów, Angyal, określa osobowość jako „rozległą postać czasową” (temporal Gestalt, za: Lindzey i Hall 1998: 250). Oznacza to jej silne osadzenie w czasie - we wszystkich wymiarach temporalnych zarówno w przeszłości, teraźniejszości, jak i przyszłości. Przeszłość i przyszłość Angyal opisuje jako nieustannie oddziałujące na teraźniejszość, a jednocześnie wciąż zmieniające swój wpływ. Przeszłość sama w sobie zdaniem autora nie jest stała i niezmienna, ponieważ dawne zdarzenia z czasem zyskują nową „wartość pozycyjną w biosferze"3 (tamże: 251). Z kolei przyszłość wpływa na teraźniejszość jako możliwość lub skłonność, również zmieniając się wraz z reorganizacją biosfery.

Zmienność przeszłości podkreśla również Rogers. Jego zdaniem osobowość człowieka składa się z dwóch powiązanych ze sobą struktur: Organizmu oraz Ja. Osobowość kumuluje doświadczenia, które tworzą tzw. pole fenomenologiczne (Lindzey i Hall 1998). Zachowanie jednostki stanowi funkcję zawartości jej pola fenomenologicznego. Jednocześnie każde nowe doświadczenie, uzupełniając zawartość pola, modyfikuje je jako całość. Oznacza to modyfikowalność przeszłości pod wpływem teraźniejszości, a dokładniej nie jej samej, lecz przeszłych doświadczeń zgromadzonych w osobowości, które zyskują nowe znaczenie dzięki doświadczeniom kolejnym. Można to interpretować jako wskazanie na rolę zarówno czasu przeszłego, jak i teraźniejszego. Tym bardziej, że koncentrację na teraźniejszości autor wymienia wśród cech tzw. w pełni funkcjonującej osoby (Lindzey i Hall 1998; Obuchowski 2000; Zając 2002).

Na szczególną uwagę zasługuje ujęcie wymiaru temporalnego osobowości autorstwa Lewina (Lindzey i Hall 1998; Zimbardo i Boyd 1999; Trempała 2000). W wielu aspektach jest ono zbliżone do ustaleń organicystów, co z resztą nie powinno dziwić, zważywszy na wspólne inspiracje psychologią postaci. Lewin był jednak pierwszym, który faktycznie, oraz w sposób świadomy i celowy, wyeksponował czasowy wymiar osobowości człowieka. W ramach teorii Lewina osoba (tworząca wraz ze środowiskiem psychologicznym przestrzeń życiową jednostki) rozpatrywana jest w przestrzennych kategoriach pola. Czasowość stanowi istotny wymiar jego organizacji. Jedna ze sformułowanych przez Lewina zasad głosi, iż zachowanie człowieka stanowi funkcję aktualnego pola, tj. pola istniejącego w tym samym czasie, w którym występuje zachowanie. Jest to tzw. zasada współczesności. Jej obowiązywanie nie oznacza jednak wyłączności roli czasu teraźniejszego, bowiem autor przedstawia teraźniejszość jako zawierającą „psychologiczną przeszłość” i „psychologiczną przyszłość” (Lewin 1951: 53-56). Psychologiczna przeszłość i przyszłość są obecne w teraźniejszości dzięki istnieniu w aktualnym polu odnoszących się do nich myśli, uczuć i postaw. W ten sposób również czas przeszły i przyszły mogą determinować zachowanie człowieka. Istotnym

3 Angyal wprowadził pojęcie biosfery w celu określenia holistycznej całości, którą jego zdaniem stanowi jednostka wraz z jej środowiskiem (Angyal 1941: 100; za: Lindzey i Hall 1998: 246). 
wyróżnikiem koncepcji Lewina jest posłużenie się pojęciem czasu psychologicznego. Inni autorzy, opisując rolę przeszłości, teraźniejszości i przyszłości, mieli na myśli realne okresy ludzkiego życia, choć jednocześnie sygnalizowali subiektywny i zmienny charakter ich znaczenia dla jednostki (np. Boss, Binswanger, Angyal, Rogers). Lewin natomiast z założenia rozpatruje czas w kategoriach psychologicznych. Jego zdaniem każdy fakt świata fizycznego (a takimi faktami w ujęciu Lewinowskim będą zdarzenia kształtujące perspektywę temporalną) musi najpierw zaistnieć w środowisku psychologicznym, zanim będzie mógł wpłynąc na osobę. Tym samym czas, który determinować może postępowanie jednostki musi być czasem psychologicznym. Tak rozumiany czas może być opisywany w wielu aspektach. Wymiar temporalny może być długi lub krótki, w zależności od tego, jak odległej przeszłości i przyszłości dotyczą myśli i uczucia jednostki. Może on być także dobrze lub słabo określony oraz prosty lub złożony w swej strukturze. Granice pomiędzy przeszłością, teraźniejszością i przyszłością mogą być mocne, oddzielając wyraźnie od siebie obszary czasu, lub słabe, gdy obszary te płynnie przechodzą jeden w drugi lub nawet się przenikają. Specyfika wymiaru czasowego osobowości podlega, zdaniem autora, rozwojowi i ulega zmianom wraz z wiekiem (Lewin 1951; Trempała 2000). Lewinowskie ujęcie temporalnego wymiaru osobowości stanowi pierwowzór dla współczesnych (przede wszystkim poznawczych) sposobów rozumienia perspektywy temporalnej.

\section{WYBRANE WSPÓŁCZESNE POLSKIE KONCEPCJE UWZGLĘDNIAJĄCE WYMIAR TEMPORALNY OSOBOWOŚCI}

Współcześnie obecność wymiaru czasu w osobowości bywa coraz częściej artykułowana wyraźnie i wprost, także w psychologii polskiej. Najwyraźniej akcentowana jest ona w koncepcjach nurtu poznawczego. Osobowość jest w jego ramach traktowana jako system odpowiedzialny za tzw. konstruowanie poznawcze. Jego ważnym elementem jest wymiar czasu. Może on funkcjonować w roli kryterium porządkowania informacji lub stanowić przedmiot poznawczego opracowania (Block 1990; Łukaszewski 1983, 1984; Nosal 2000; Nosal i Bajcar 2004; Quadrio 1988; Seijts 1998; Trempała 2000; Zając-Lamparska 2010, 2011; Zimbardo i Boyd 2009).

Problematyka rozważań i badań prowadzonych w tym nurcie, zarówno w psychologii polskiej, jak i światowej, obejmuje zazwyczaj następujące zagadnienia: perspektywę temporalną, orientację temporalną i kompetencję temporalna, postawy temporalne i osobiste koncepcje czasu ${ }^{4}$. Jest to widoczne zarówno w psychologii światowej, jak i polskiej (Bajcar 2000; Block 1990; Lens 2006; Nosal 1993, 2000; Nosal i Bajcar 2004; Nuttin i Lens 1985; Sobol 2002; Trempała 2000; Uchnast 2006).

Perspektywa temporalna stanowi kategorię najszerszą i oznacza kognitywną reprezentację wymiaru, przebiegającego od przeszłości ku przyszłości, w którym jednostka lokuje osobiste wydarzenia i przeżycia (Block 1990; Łukaszewski 1983, 1984; Nosal 2000; Trempała 2000).

4 Zapewne kategorii analizowanych w ramach poznawczego podejścia jest więcej, wymienione należą jednak do najczęstszych. 
Analizując perspektywę temporalną w kontekście osobowościowym, można wskazać takie jej cechy jak: ilościowo-jakościowy i obiektywno-subiektywny charakter, holizm i jednocześnie otwartość ${ }^{5}$ (Zając-Lamparska 2010).

Termin orientacja temporalna odnosi się do preferowanego przez jednostkę ukierunkowania temporalnego (na przeszłość, teraźniejszość lub przyszłość) jej aktywności behawioralnej i psychicznej (Block 1990; Cottle i Klineberg 1974, za: Tarkowska 1987; Lens 2006; Łukaszewski 1983).

Kompetencja temporalna oznacza stopień integracji wymiarów przeszłości, teraźniejszości i przyszłości, doświadczanie ich ciąłości, a także otwarcie na teraźniejszość, u podstaw którego leży jednoczesna akceptacja przeszłości i uwzględnianie przyszłości oraz starań o nią (Lens 2006; Nuttin i Lens 1985; Uchnast 2006; Uchnast i Tucholska 2003).

Pod pojęciem osobistej koncepcji czasu kryją się natomiast funkcjonujące na poziomie poznawczym jednostkowe przekonania co do istoty i natury czasu (Bajcar 2000).

Niekiedy osobista koncepcja czasu utożsamiana bywa z postawami temporalnymi, czyli postawami jednostki wobec czasu jako takiego lub wobec jego wymiarów: przeszłości, teraźniejszości i przyszłości (Nosal 2000). Różnicę pomiędzy tymi dwoma konstruktami wyznacza wyraźnie ewaluacyjny charakter postaw, będący tylko możliwym, lecz nie integralnym elementem osobistych koncepcji czasu (Bajcar 2000).

Jednocześnie zauważyć można, że wymiar czasu w ujęciu poznawczym jest wiązany z osobowością w dwojakiego rodzaju sposób:

- Istnieją koncepcje osobowości, w ramach których horyzont czasowy bywa umieszczany bezpośrednio w strukturze osobowości i opisywany jako jej element.

- W innych ujęciach określone charakterystyki temporalne (jak orientacja temporalna czy postawy temporalne) są uznawane za istotny wyznacznik dynamiki ludzkiego zachowania oraz wiązane z wybranymi właściwościami osobowościowymi.

W psychologii polskiej podejście pierwsze reprezentują koncepcje Łukaszewskiego (1983, 1984) czy Reykowskiego (Reykowski i Kochańska 1980). Przy czym Łukaszewski nie tylko wpisuje perspektywę temporalną w strukturę osobowości, lecz również wskazuje, jak poszczególne orientacje temporalne wiążą się z innymi aspektami osobowości i przekładają się na tendencje do określonych zachowań. W koncepcji Łukaszewskiego wymiar temporalny stanowi integralny aspekt osobowości $(1983,1984)$. Osobowość autor rozpatruje w kategoriach poznawczych jako „ten fragment mechanizmów regulacji zachowania się, który jest rezultatem uczenia się i kumulowania doświadczenia oraz wynikiem rozwoju (restrukturyzacji) skumulowanego doświadczenia” (Lukaszewski 1984: 16). W ramach struktury osobowości Łukaszewski wyróżnia dwojakiego rodzaju aspekty: deskryptywne i ewaluatywne. Deskryptywne aspekty osobowości stanowią opisy: obiektów, zjawisk, stanów rzeczy, relacji pomiędzy nimi itp. Opisy te podlegają uporządkowaniom na podstawie różnych zasad. Jedną z nich, której znaczenie autor podkreśla, jest zasada temporalna (tamże). Organizuje ona wszelkie opisy na kontinuum przeszłe - teraźniejsze - przyszłe.

5 W tym sensie, że perspektywa temporalna nigdy nie osiaga stanu constans. Podlega nieustannym przekształceniom wskutek aktywności życiowej i poznawczej człowieka. 
Łukaszewski nazywa opisy stanów przeszłych i aktualnych elementami poznawczymi osobowości, argumentując, iż są one znane jednostce z doświadczenia indywidualnego lub przekazu społecznego, co oznacza, że były przedmiotem poznania czy uczenia się. Z kolei reprezentacje stanów przyszłych określa on jako projekcyjne elementy osobowości. Należą do nich opisy dwojakiego rodzaju: prognozy oraz wyobrażenia stanów możliwych. Prognozom zazwyczaj przypisane jest wyższe prawdopodobieństwo niż wyobrażeniom stanów możliwych. Swego rodzaju uzupełnienie deskryptywnych aspektów osobowości stanowiąjej aspekty ewaluatywne (tamże). W ich ramach formułowane są dwa typy ocen: po pierwsze dotyczące wartościowości, czyli „dobroci”, emocjonalnie pozytywnego vs negatywnego charakteru stanów, obiektów itd. oraz, po drugie, dotyczące ich doniosłości. Znaczącym elementem koncepcji Łukaszewskiego jest przyjęcie założenia o niesamodzielnym statusie ocen wartościujących. Zdaniem autora funkcjonują one bowiem jako towarzyszące elementom deskryptywnym. W ten sposób każdy obiekt czy stan rzeczy, opisany w wymiarze temporalnym, ma jednocześnie swą lokalizację na skali wag i wartościowań. Oceny wartościujące, dotycząc konkretnych obiektów i stanów, mogą addytywnie decydować o ewaluacji całych obszarów czasowych (przeszłości, teraźniejszości i przyszłości), w których się mieszczą. Ich wagi i wartościowości wspólnie kształtują orientację temporalną jednostki. Waga wyznacza doniosłość poszczególnych wymiarów czasu, orientując jednostkę na jeden (lub kilka) z nich. Z kolei wartościowość decyduje o pozytywnym lub negatywnym emocjonalnie znaku takiej orientacji. Oba czynniki mają możliwość ukierunkowywania ludzkiej aktywności. Podstawę tego stanowi hierarchia wartościowań i wag. Pozycja zajmowana w niej przez poszczególne obiekty decyduje o uporządkowaniu ich wpływu na zachowanie jednostki, czyli o ich tzw. mocy regulacyjnej. Pojęcie to można stosować zarówno do prostych elementów, jak i całych ich zbiorów czy podsystemów osobowości, jak np. kontinuum temporalne i jego obszary: przeszłość, teraźniejszość i przyszłość. Od posiadanej przez nie mocy regulacyjnej będzie zależał ich udział w regulacji zachowania człowieka. Autor opisuje specyfikę tej regulacji w zależności od orientacji na przeszłość, teraźniejszość lub przyszłość oraz od „znaku” tej orientacji, budując typologię, opartą na kryterium orientacji temporalnej. Wyróżnia on trzy „czyste” typy orientacji temporalnej: retrospektywny, prezentystyczny i futurystyczny oraz typy mieszane, np. retrospektywno-prezentystyczny, prezentystyczno-futurystyczny (tamże).

Perspektywę temporalną włącza w strukturę osobowości także Reykowski (Reykowski i Kochańska 1980). W ujęciu tego autora osobowość zyskuje wymiar czasowy w wyniku umieszczenia Struktury Ja w Sieci Operacyjnej, a dokładniej w temporalnym porządku deskryptywnym (tamże).

Z kolei do polskich autorów, którzy łączą temporalność z dynamiką zachowania i osobowościowymi determinantami tej dynamiki, należą m.in.: Nosal (1993, 2000, Nosal i Bajcar 2004), Mądrzycki (1996), Obuchowski (1985, 1997, 2000), Strzałecki (2003, 2006) i Zaleski (1988, 1994).

Nosal w swych badaniach prowadzonych wspólnie z Bajcar (Nosal i Bajcar 2004) uwzględnia wiele aspektów temporalności (orientacje temporalne, postawy temporalne, osobiste koncepcje czasu) i wiąże je z cechami osobowości oraz sferą motywacji i potrzeb. Rezultat tych szeroko zakrojonych badań stanowi identyfikacja dwóch zasadniczych profili 
Temporalny wymiar osobowości. Panorama stanowisk

temporalności, które zostały określone jako proaktywny i reaktywny (Bajcar 2006; Nosal i Bajcar 2004).

Profil proaktywny charakteryzuje wyraźna koncentracja na przeszłości i przyszłości, przy jednoczesnym małym ukierunkowaniu na czas teraźniejszy. Zdaniem autorów tworzy to szeroką perspektywę temporalną, która stanowi odzwierciedlenie dużego stopnia umysłowej integracji przeszłych, teraźniejszych i przyszłych doświadczeń (Bajcar 2006). Kolejnymi cechami opisywanego profilu są: wysoki poziom teliczności ( $\mathrm{tj}$. ukierunkowania zachowania na cele), tendencji do planowania i szczegółowości oraz poczucie wykorzystania czasu i duża odporność na presję czasu. Cechy te warunkują sprawną temporalną organizację działania. Postawy wobec czasu osób przejawiających profil proaktywny są pozytywne. Osoby te postrzegają czas jako konstruktywny i sprzyjający człowiekowi, a jednocześnie uporządkowany i poddający się kontroli. W ocenie badaczy profil proaktywny wyraża „konstruktywny wzorzec temporalności” (Nosal i Bajcar 2004: 114), w ramach którego aktywność jest ukierunkowana na czas przyszły i wykracza poza wymogi aktualnej sytuacji. Towarzyszy temu tendencja do poszerzania kontroli nad czasem (tamże).

Profil reaktywny stanowi przeciwieństwo proaktywnego (Bajcar 2006; Nosal i Bajcar 2004). Jego specyfika obejmuje: silną koncentrację na teraźniejszości kosztem czasu przeszłego i przyszłego, co zawęża perspektywę temporalną jednostki; niski poziom teliczności, brak skłonności do planowania i szczegółowości. Towarzyszy temu poczucie silnej presji czasu i niedostatecznego jego wykorzystywania. Postawy wobec czasu mają w tym przypadku charakter negatywny- czas jest odbierany jako destruktywny i wrogi, a jednocześnie wymykający się spod kontroli. Zdaniem badaczy osoby o temporalnym profilu reaktywnym cechuje doraźny, bezpośredni sposób reagowania i brak dystansu wobec sytuacji. W połączeniu z brakiem zdolności do poznawczego kontrolowania czasu przyczynia się to do przyjmowania strategii działania zawężonej do bieżącej aktywności i nadaje koncentracji na teraźniejszości charakter obronny (Nosal i Bajcar 2004).

Jeśli chodzi o związek profili temporalnych z cechami osobowości wymienianymi w pięcioczynnikowym modelu osobowości Costy i McCrae'a, osoby o profilach proaktywnym i reaktywnym różnią się pod względem nasilenia wszystkich cech, poza ugodowością. Profilowi proaktywnemu towarzyszy wyższy poziom ekstrawersji, otwartości i sumienności oraz niższy poziom introwersji niż ma to miejsce w przypadku profilu reaktywnego (tamże).

W obszarze potrzeb i motywacji posiadanie proaktywnego profilu temporalnego wiąże się z dużym nasileniem potrzeb dotyczących realizacji celów życiowych, wytrwałością w działaniu, rzetelnością i odpowiedzialnością, twórczością i zdolnościami przywódczymi. Charakterystykę tę uzupełniają cechy wskazujące na dojrzałość osobowości (wysoki poziom przystosowania, zgodność osobowości z ideałem, kontrola emocjonalna i zaufanie do siebie) oraz na posiadanie kompetencji interpersonalnych (łatwość nawiązywania pozytywnych relacji emocjonalnych, gotowość do współdziałania i do pomocy innym) (tamże). Z kolei dla osób o temporalnym profilu reaktywnym charakterystyczna jest impulsywność i zmienność, trudności w mobilizowaniu się do wysiłku, brak wytrwałości w osiaganiu celów życiowych, duża ostrożność i brak zdecydowania w podejmowaniu zadań oraz łatwość rezygnacji z zadań już podjętych. W obszarze relacji interpersonalnych tych osób występuje lęk i poczucie 
nieprzystosowania oraz tendencja do utrzymywania dystansu wobec ludzi. Dominują u nich potrzeby niezależności i indywidualizmu. Dojrzałość osobowości, kontrola emocjonalna oraz akceptacja siebie i zdolność do radzenia sobie w sytuacjach trudnych są tu niższe niż ma to miejsce w przypadku profilu proaktywnego (tamże).

Badania Nosala i Bajcar dowodzą, że czas jest nie tylko ważną kategorią ludzkiego umysłu, lecz również ważnym aspektem charakterystyki osobowościowej jednostki.

Z kolei Obuchowski, Mądrzycki, Strzałecki i Zaleski zajmują się zagadnieniem celów i zadań oraz planów życiowych ${ }^{6}$ człowieka, przy czym do kategorii temporalności sensu stricto najwyraźniej odwołuje się Strzałecki (2003, 2006). Zaleski $(1988,1994)$ koncentruje się na orientacji futurystycznej i jej znaczeniu, natomiast Obuchowski $(1985,1997)$ i Mądrzycki (1996) również podkreślają rolę czasu przyszłego w funkcjonowaniu człowieka, niekoniecznie posługując się przy tym terminologią z zakresu psychologii temporalności. Nie sposób zawrzeć w artykule całości rozważań teoretycznych oraz rezultatów badań empirycznych wskazanych autorów, stąd omówię dwa korespondujące ze sobą ujęcia: koncepcję teoretyczną Obuchowskiego oraz empiryczne ustalenia Strzałeckiego.

Obuchowski (1985) nie umieszcza w strukturze osobowości perspektywy temporalnej sensu stricto, czyni to jednak pośrednio, lokując w niej zadania. W koncepcji tego autora system osobowościowy złożony jest $\mathrm{z}$ dwóch zasadniczych podsystemów: układu bazalnego i układu programującego. Układ bazalny obejmuje te właściwości psychiczne jednostki, u podstaw których leży określona specyfika CUN, natomiast w układzie programującym mieszczą się właściwości osobowości wynikające $\mathrm{z}$, właściwej jednostce, organizacji informacji. Jedną z form organizacji wiedzy jednostki stanowią właśnie zadania osobiste (tamże). Opisując zadania, Obuchowski przeprowadza ich taksonomię, a następnie, uwzględniając wyróżnione przez siebie typy zadań, wyszczególnia możliwe formy ich organizacji (1985, 1997). Organizację tę kształtują różne konfiguracje trzech rodzajów zadań, różniących się poziomem ogólności. Są to: (1) zadania nadrzędne - o najwyższym poziomie ogólności, pełniące funkcję wartości uzasadniających pozostałe; (2) zadania operacyjne - już operacjonalizujące zadania nadrzędne, ale jeszcze dość ogólne, przybierające często postać warunkową; (3) zadania konkretne - ukonkretniające założenia zadań operacyjnych, zakładające tylko jeden planowany stan rzeczy. Autor wyróżnia pięć możliwych sposobów organizacji zadań: luźny, liniowy, niepełny, pseudohierarchiczny i hierarchiczny. Optymalny ze względu na funkcjonowanie osobowości jest typ hierarchiczny. Obejmuje on wszystkie rodzaje zadań, w specyficznym ich powiązaniu, o charakterze relacji nadrzędności-podrzędności. Relacja ta nie tylko określa rangę poszczególnych zadań, lecz oznacza również, iż zadania niższe w hierarchii służą realizacji zadań wyższych. Na szczycie hierarchii znajdują się zadania najbardziej ogólne. Najczęściej przyjmują one postać abstrakcyjnej wartości. Jednocześnie, aby wartość mogła wyznaczać realne postępowanie jednostki, musi zostać ukonkretniona. Temu służą, powiązane z zadaniem ogólnym, zadania operacyjne i konkretne. Te pierwsze tylko

${ }^{6}$ Wpisuje się to w nurt takich koncepcji jak: koncepcja zadań życiowych Cantor, koncepcja dążeń osobistych Emmonsa, koncepcja projektów osobistych R. Little’a, koncepcja możliwych Ja Markusa, koncepcje celów Forda, Pervina i in. (Mądrzycki, 1996; Pervin, 2002). 
ukierunkowują aktywność człowieka, drugie natomiast wyrażają jej konkretne i faktycznie obserwowane formy (Obuchowski 1985, 2000).

Z charakterystyką hierarchicznego typu organizacji zadań koresponduje wskazywana przez Obuchowskiego funkcja osobowości, którą stanowi adaptacja twórcza (1985, 1997, 2000). Pod tym pojęciem autor rozumie adaptowanie się osobowości nie do stanów aktualnych, lecz przyszłych, w tym również do stanów samodzielnie zaprojektowanych. Adaptacja twórcza stanowi jednocześnie mechanizm rozwoju osobowości. Poza nią autor wymienia jeszcze trzy inne rodzaje adaptacji: mechaniczną, neurotyczną i bierną, które nie mają charakteru rozwojowego (Obuchowski 1985, 1997).

Strzałecki umieszcza swe badania w kontekście teoretycznym modelu teleologicznego człowieka, charakterystycznego również dla koncepcji Obuchowskiego i zakładającego, że istotę procesu samorealizacji stanowi osiaganie stawianych sobie celów (Strzałecki 2003). Cele te lokowane są w wymiarze przyszłym przestrzeni czasowej, dlatego Obuchowski funkcją osobowości czyni „opanowywanie przyszłości za pomocą czynności twórczych” (Obuchowski 1985: 197). Stąd też wywodzi się teza, stawiana przez Strzałeckiego (2003), że temporalna charakterystyka celów będzie pozostawać w związku z właściwościami osobowości. Strzałecki (2003, 2006) w swych badaniach postawił sobie za zadanie ustalenie, czy umiejscowienie celów i wydarzeń życiowych w czasie psychologicznym (w psychologicznej przyszłości) jest związane z poczuciem kontroli nad nimi, subiektywnym prawdopodobieństwem ich osiagnięcia/wystąpienia oraz z zaangażowaniem emocjonalnym wobec nich.

Rezultaty badań pozwoliły stwierdzić, że cele i wydarzenia, co do których jednostka przejawia wyższe poczucie kontroli są postrzegane przez nią jako bardziej prawdopodobne i jednocześnie ich wystąpienie jest umiejscawiane bliżej w czasie psychologicznym. Obie zależności mają charakter nieco silniejszy w przypadku celów niż w przypadku wydarzeń (Strzałecki 2003, 2006). Na podstawie uzyskanych wyników badań oraz analizy szeregu ujęć teoretycznych Strzałecki (2003) stawia tezę, że osoby o wysokich kompetencjach intelektualnych, charakteryzujące się wewnątrzsterownością i wysoką motywacją osiągania celów, potrafiące przezwyciężyć lęk związany z trudnościami na drodze realizacji celów dzięki dużej sile ego, będą postrzegać cele jako bardziej prawdopodobne do osiągnięcia i mniej odległe w czasie psychologicznym.

Kolejna ważna prawidłowość ustalona w omawianych badaniach polega na tym, że ludzie przejawiają szczególnie duże zaangażowanie emocjonalne wobec tych celów życiowych, które są lokowane w czasie psychologicznym blisko oraz daleko. Przy czym w przypadku celów dalekich duży ładunek emocjonalny występuje tylko przy jednoczesnym poczuciu wysokiej kontroli nad realizacją danego celu (tamże). Ten rezultat interpretować można w kontekście koncepcji Obuchowskiego, uznając cele odległe w czasie, których realizacja podlega kontroli i angażuje emocjonalnie, za stymulujące proces adaptacji twórczej zadania dalekie (Obuchowski 1987, 1997, 2000). Do podobnej interpretacji odwołuje się zresztą sam Strzałecki (2003).

Zestawienie ujęcia teoretycznego Obuchowskiego i rezultatów badań Strzałeckiego oraz wykazanie ich koherencji stanowi istotną przesłankę na rzecz wniosku, że czas psychologiczny jest dla psychologii osobowości kategorią ważną i wartą uwzględniania, tak w koncepcjach teoretycznych, jak i w badaniach empirycznych. 


\section{PODSUMOWANIE}

Porównując klasyczne koncepcje osobowości i koncepcje współczesne, podejmujące temat temporalności, zauważyć można kilka wyraźnych zmian.

Najbardziej podstawowa $\mathrm{z}$ nich polega na tym, że status zagadnienia czasu w psychologii osobowości ewoluował od problemu „drugoplanowego”, stanowiącego swoiste tło dla ważniejszych kwestii i tylko sygnalizowanego, do centralnego, stanowiącego podstawowy przedmiot rozważań i badań.

Nastąpiło też przesunięcie od obiektywnego do subiektywnego ujęcia czasu, tj. od przyjmowania perspektywy zewnętrznej i wykorzystywania czasu jako parametru czy kryterium opisu ludzkiego zachowania, do zainteresowania czasem psychologicznym, stanowiącym kategorię umysłu człowieka i obligującym do rozpatrywania temporalności z wewnętrznej perspektywy samej jednostki .

Powiązane z tą zmianą (prawdopodobnie w sposób dwukierunkowy) były rozwój i stopniowa dominacja podejścia poznawczego do temporalnej problematyki osobowości.

Ważne zjawisko stanowi też rosnąca tendencja do poddawania tej problematyki empirycznej eksploracji. W zasadzie dopiero przyjęcie perspektywy poznawczej skłoniło psychologów osobowości do podjęcia badań empirycznych nad zagadnieniem temporalności, choć dużo wcześniej były one prowadzone w innych obszarach, np. w obszarze psychofizyki (Nosal i Bajcar 2004; Zając-Lamparska 2011). Konsekwencję włączenia zagadnienia czasu w zakres empirycznych problemów psychologii osobowości stanowiło (i stanowi) powstawanie narzędzi do badania czasu psychologicznego, z których część jest inspirowana metodami stosowanymi w psychofizyce, inne mają charakter kwestionariuszowy - bardziej typowy dla psychologii osobowości (np. Cottle 1968, za: Łukaszewski, 1983; Nosal i Bajcar 2004; Strzałecki 2003, 2006; Teuscher i Mitchell 2011; Uchnast i Tucholska 2003; Webster 2011; Zimbardo i Boyd 1999, 2009).

Obserwując wzrost zainteresowania temporalnym aspektem ludzkiej osobowości, następujący wraz z przyrostem i pogłębianiem się wiedzy na jego temat, można stwierdzić, że choć ludzka osobowość zawsze miała swój wymiar temporalny (o czym świadczy obecność zagadnienia czasu nawet w koncepcjach, których twórcy wydawali się temporalnością nie interesować), to istnienie i znaczenie tego wymiaru musiało zostać przez psychologów uświadomione, by mogli oni uczynić go jednym z kluczowych elementów poznania człowieka.

\section{BIBLIOGRAFIA}

Adler, Alfred. 1986. Sens życia, Warszawa: Wydawnictwo Naukowe PWN. Allport, Gordon. 1988. Osobowość i religia, Warszawa: Instytut Wydawniczy „Pax”.

\footnotetext{
7 Nie oznacza to oczywiście, że współcześnie zarzucono badania, w których czas wykorzystywany jest jako zewnętrzne kryterium czy parametr, jednak w obszarze psychologii osobowości dominujące jest aktualnie zainteresowanie czasem psychologicznym - o charakterze wewnętrznym i subiektywnym, niezdeterminowanym obiektywnym czasem fizycznym, choć niewątpliwie w pewnym stopniu z nim związanym.
} 
Bajcar, Beata. 2000. Wielowymiarowość osobistych koncepcji czasu, „Roczniki Psychologiczne" 3: 71-93.

Bajcar, Beata. 2006. Individual Differences in Temporal Orientation - Research Results, w: Zenon Uchnast (red.), Psychology of Time, Lublin: Wydawnictwo KUL, s. 109-131.

Block, Richard. 1990. Models of Psychological Time, w: Richard Block (red.), Cognitive Models of Psychological Time, Hillsdale: Lawrence Erlbaum Associates, s. 1-35.

Dollard, John i Neal Miller. 1967. Osobowość i psychoterapia, Warszawa: PWN.

Freud, Zygmunt. 1995. Wstęp do psychoanalizy, Warszawa: PWN.

Gałdowa, Anna. 1999. Psychologia analityczna C.G. Junga, w: Anna Gałdowa (red.), Klasyczne i współczesne koncepcje osobowości, Kraków: Wydawnictwo UJ, s. 57-86.

Lens, Willy. 2006. Future Time Perspective: A Psychological Approach, w: Zenon Uchnast (red.), Psychology of Time, Lublin: Wydawnictwo KUL, s. 51-64.

Lewin, Kurt. 1951. Field Theory in Social Science. New York: Harper and Row.

Lindzey, Gardner i Calvin Hall. 1998. Teorie osobowości, Warszawa: Wydawnictwo Naukowe PWN.

Łukaszewski, Wiesław. 1983. Orientacja temporalna jako jeden z aspektów osobowości, w: Wiesław Łukaszewski (red.), Osobowość - orientacja temporalna - ustosunkowanie do zmian, Wrocław: Wydawnictwo Uniwersytetu Wrocławskiego, s. 5-39.

Łukaszewski, Wiesław. 1984. Szanse rozwoju osobowości, Warszawa: Wydawnictwo „Książka i Wiedza".

Mądrzycki, Tadeusz. 1996. Osobowość jako system tworzacy i realizujacy plany, Gdańsk: GWP.

Nosal, Czesław. 1993. Style percepcji czasu: wymiary i struktura. Propozycja nowej skali pomiarowej, w: Jerzy Brzeziński (red.), Psychologiczne i psychometryczne problemy diagnostyki psychologicznej, Poznań: Wydawnictwo UAM, s. 121-141.

Nosal, Czesław. 2000. Czas jako wymiar regulacji zachowania. Problemy psychologii temporalnej, w: Jerzy Brzeziński i Stanisław Kowalik (red.), O różnych sposobach uprawiania psychologii, Poznań: Zysk i S-ka, s. 106-130.

Nosal, Czesław i Beata Bajcar. 2004. Czas psychologiczny: wymiary, struktura, konsekwencje, Warszawa: Wydawnictwo Instytutu Psychologii PAN.

Nuttin, Joseph i Willy Lens. 1985. Future Time Perspective and Motivation: Theory and Research Method, Leuven \& Hillsdale: Leuven University Press \& Erlbaum.

Obuchowski, Kazimierz. 1985. Adaptacja twórcza, Warszawa: Książka i Wiedza.

Obuchowski, Kazimierz. 1997. Zmiany osobowości - założenia i tezy, „Forum Psychologiczne" 2: 22-30.

Obuchowski, Kazimierz. 2000. Galaktyka potrzeb, Poznań: Zysk i S-ka.

Opoczyńska, Małgorzata. 1999. Sama Keena ,mityczna podróż do wewnątrz”, w: Anna Gałdowa (red.), Wybrane zagadnienia z psychologii osobowości, Kraków: Wydawnictwo UJ, s. 139-150.

Pervin, Lavrence i Oliver John. 2002. Osobowość. Teoria i badania, Kraków: Wydawnictwo UJ.

Pervin, Lawrence. 2002. Psychologia osobowości, Gdańsk: GWP.

Quadrio, Assuanto. 1988. Wymiar czasu w psychologii politycznej, „Przegląd Psychologiczny" 3: 745-751. 
Reykowski, Janusz i Grażyna Kochańska. 1980. Szkice z teorii osobowości, Warszawa: Wiedza Powszechna.

Seijts, Gerard. 1998. The Importance of Future Time Perspective in Theories of Work Motivation, "The Journal of Psychology" 2: 154-168.

Sobol, Małgorzata. 2002. Metafora jako sposób ekspresji postaw temporalnych, „Roczniki Psychologiczne" 5: 115-127.

Stevens, Robert. 2000. Freudowskie teorie osobowości, w: Sarah Hampson i Andrew Colman (red.), Psychologia różnic indywidualnych. Poznań: Zysk i S-ka, s. 86-107.

Strzałecki, Andrzej. 2003. Psychologia twórczości. Między tradycja a ponowoczesnościa, Warszawa: Wydawnictwo UKSW.

Strzałecki, Andrzej. 2006. Psychological Time and the Subjective Probability of Attaining Life Goals, w: Zenon Uchnast (red.), Psychology of Time, Lublin: Wydawnictwo KUL, s. 79-96.

Tarkowska, Elżbieta. 1987. Czas w społeczeństwie. Problemy, tradycje, kierunki badań, Wrocław: Ossolineum.

Teuscher, Ursina i Suzanne Mitchell. 2011. Relation between Time Perspective and Delay Discounting: A Literature Review, "The Psychological Record" 4: 613-632.

Trempała, Janusz. 2000. Modele rozwoju psychicznego. Czas i zmiana, Bydgoszcz: Wydawnictwo $\mathrm{AB}$.

Uchnast, Zenon. 2006. Temporal Competencies - Quantitative and Qualitative Approaches, w: Zenon Uchnast (red.), Psychology of Time, Lublin: Wydawnictwo KUL, s. 143-160.

Uchnast, Zenon i Kinga Tucholska. 2003. Kompetencje temporalne-metoda pomiaru, „Roczniki Psychologiczne" 6: 131-150.

Webster, Jeffrey. 2011. A New Measure of Time Perspective: Initial Psychometric Findings for the Balanced Time Perspective Scale (BTPS), "Canadian Journal of Behavioural Science" 2: 111-118.

Zając, Ludmiła. 2002. Psychologiczna sytuacja człowieka starszego oraz jej determinanty, w: Kazimierz Obuchowski (red.), Starość i osobowość, Bydgoszcz: Wydawnictwo AB, s. 53-112.

Zając, Ludmiła. 2003. Temporal frameworks in the dynamics of self-authoring, w: Bruce Duncan MacQueen i Maria Pąchalska (red.), Society as Text in the Thought of Richard Harvey Brown, Wrocław: Continuo Publishing House, s. 141-159.

Zając-Lamparska, Ludmiła. 2010. Specyfika perspektywy temporalnej w okresie wczesnej i późnej dorostości, w: Elżbieta Rydz i Dagmara Musiał (red.), Z zagadnień psychologii rozwoju człowieka. Tom III, Lublin: Wydawnictwo Towarzystwa Naukowego KUL JPII, s. 155-176.

Zając-Lamparska, Ludmiła. (2011). Czas jako kryterium opisu oraz mechanizm regulacji ludzkiego zachowania - problematyka czasu w psychologii, „Przegląd Naukowo-Metodyczny Edukacja dla Bezpieczeństwa" 4: 111-124.

Zaleski, Zbigniew. 1988. Transtemporalne “Ja”: osobowość w trzech wymiarach czasowych. „Przegląd Psychologiczny” 4: 931-945.

Zaleski, Zbigniew. 1994. Towards a Psychology of the Personal Future, w: Zbigniew Zaleski (red.), Psychology of Future Orientation, Lublin: Towarzystwo Naukowe KUL, s. 10-20. 
Zimbardo, Philip i John Boyd. 1999. Putting Time in Perspective: A Valid, Reliable Individual-Differences Metric, "Journal of Personality and Social Psychology" 6: 1271-1288.

Zimbardo, Philip. i John Boyd. 2009. Paradoks czasu. Warszawa: Wydawnictwo Naukowe PWN.

\section{TEMPORAL DIMENSION OF PERSONALITY. THE REVIEW OF DIFFERENT APPROACHES}

The aim of this article is to review and analyze the psychological concepts of personality in terms of the presence of time issue (in them). The analysis shows that the time can play a role of an external criterion for the description of the functioning of the personality, or be present in the personality itself as psychological time. Status of time issues in psychology of personality has evolved from a secondary problem, which was a kind of background for the most important matters and just signaled, to the central problem which is the primary subject of concern, debate and research. Nowadays, temporal aspects of personality are analyzed and empirical studied, especially in the cognitive approach.

Key words: personality, psychological time, temporal perspective, temporal orientation 